\title{
Fe-EDTA-BISAMIDE AND Fe-ADR-925, THE IRON-BOUND HYDROLYSIS PRODUCT OF THE CARDIOPROTECTIVE AGENT DEXRAZOXANE, CLEAVE DNA VIA THE HYDROXYL RADICAL
}

\author{
Thomas J. Magliery," Lizabeth K. Vitellaro, Ndeye Khady Diop \\ and Rosemary A. Marusak ${ }^{\star}$ \\ Department of Chemistry, Kenyon College, Gambier, OH 43022, USA
}

\begin{abstract}
Use of the antitumor drug doxorubicin is limited by cardiomyopathic side-effects which are believed to be due to iron-mediated hydroxyl radical generation. Dexrazoxane reduces this cardiotoxicity, possibly by removal of iron from doxorubicin by the EDTA-like hydrolysis product of dexrazoxane, ADR-925. However, EDTA-diimides like dexrazoxane, previously used as antitumor agents, are themselves carcinogenic, and recent studies have found that Fe-ADR-925 can also promote hydroxyl radical production. This study demonstrates that, like Fe-EDTA, Fe-ADR-925 and a related desmethyl complex can cleave plasmid DNA under Fenton conditions, and suggests by radical scavenger study that this cleavage is probably via the hydroxyl radical. Differences in DNA cleavage dependence upon concentrations of Fe-EDTA, Fe-ADR-925 and Fe-EDTA-bisamide can be explained by differences in the solution chemistry of the complexes.
\end{abstract}

\section{Introduction}

Dexrazoxane (Zinecard, Cardioxane, ADR-529, ICRF-187), 1, reduces the cardiomyopathic effects of the antitumor antibiotic doxorubicin (Adriamycin), effectively raising the lifetime maximum dose of doxorubicin. ${ }^{1}$ The cardiotoxicity of doxorubicin is believed to be due to an iron-mediated production of reactive hydroxyl radicals, HO , which have been associated with lipid peroxidation and protein and nucleic acid cleavage. ${ }^{2,3}$ It is generally thought that the nonpolar dexrazoxane hydrolyzes intracellularly to 2 (ADR-925), a polar bisamide/bisacid analog of the metal ion chelator EDTA (3), reducing the availability of iron to doxorubicin and, hence, the production of hydroxyl radicals. ${ }^{2}$ In addition to the enantiomerically-pure dexrazoxane, both its racemate razoxane (ICRF-159) and its desmethy! form (ICRF-154, EDTA-diimide, 4), are alone effective against murine tumor models. ${ }^{4,5}$ Razoxane was previously used to treat breast masses as well as psoriasis, but treatment with EDTA-diimide derivatives led to generalized carcinogenesis as therapy-related leukemia. 5,6 Like doxorubicin, razoxane is thought to target topoisomerase II (although by a different mechanism); however it was shown to hydrolyze intracellularly and was initially thought to be involved in metal ion chelation. ${ }^{7-11}$

Dexrazoxane is prescribed at lower doses in cardioprotection $\left(500-600 \mathrm{mg} / \mathrm{m}^{2}\right)$ than razoxane was as an antineoplastic $\left(500-1500 \mathrm{mg} / \mathrm{m}^{2}\right)$, but an important therapeutic issue is the limit of the ability of dexrazoxane to reduce doxorubicin-related toxicity, especially since razoxane was shown to act synergistically with doxorubicin as an antitumor agent. ${ }^{5,12}$ Indeed, Imondi et al. recently showed that proportionally greater doses of dexrazoxane are poorer inhibitors of cardiomyopathy at increasing doses of doxorubicin in animal models. ${ }^{13}$ Hasinoff and Winterbourn have illustrated the ability of the hydrolysis product of razoxane (ICRF-198, the racemate of ADR-925) to remove iron(III) from doxorubicin, and there is recent evidence that the iron-bound hydrolysis product of dexrazoxane is involved in hydroxyl-radical production. ${ }^{14,15}$ Winterbourn, et al., illustrated this production by showing oxidation of small, organic molecules in the presence of Fe-ADR-925 comparable to Fe-EDTA. ${ }^{15}$ Hasinoff and associates have shown that this can involve direct reaction of doxorubicin to reduce the $\mathrm{Fe}$ ADR-925 and have additionally suggested that Fe-ADR-925 produces hydroxyl radicals more slowly than Fe-EDTA. ${ }^{16,17}$

"Current Address: Department of Chemistry, University of California, Berkeley, CA 94720, USA 
<smiles>C[C@@H](CN1CC(=O)NC(=O)C1)N1CC(=O)NC(=O)C1</smiles>

1 dexrazoxane<smiles>C[C@@H](CN(CC(N)=O)CC(=O)O)N(CC(N)=O)CC(=O)O</smiles>

2 ADR-925<smiles>O=C(O)CN(CCN(CC(=O)O)CC(=O)O)CC(=O)O</smiles>

3 EDTA<smiles>O=C1CN(CCN2CC(=O)N[C@@H](O)C2)CC(=O)N1</smiles>

4 ICRF-154<smiles>NC(=O)CN(CCN(CC(N)=O)CC(=O)O)CC(=O)O</smiles>

5 EDTA-bisamide

Fe-ADR-925 is presumed to react like Fe-EDTA under Fenton conditions (in the presence of oxidant and reductant). ${ }^{15}$ The Fenton reaction involves reduction of the ferric species to the corresponding ferrous species, followed by reduction of dioxygen to hydrogen peroxide or reduction of hydrogen peroxide to a hydroxide and hydroxyl radical; other electron-deficient species may also be produced, depending upon the iron ligand. ${ }^{3}$ In particular, these reactive, oxidizing species are exploited in nucleic acid and protein cleavage studies, and it has specifically been illustrated that Fe-EDTA cleaves DNA under Fenton conditions via the hydroxyl radical. ${ }^{3,18}$

Since doxorubicin is a DNA intercalator, it is reasonable to think that some of the hydroxyl radicals produced by the doxorubicin oxidize and cleave DNA in vivo, and this may account in part for the cardiotoxicity of doxorubicin. However, since Fe-ADR-925 produces hydroxyl radicals similarly to Fe-EDTA, it is of great importance to consider whether this ironbound hydrolysis product of dexrazoxane can also cleave DNA. A particularly useful assay for hydroxyl radical damage to DNA is the nicking of a supercoiled plasmid. . $^{19-23}$ The supercoiled form (form I) of the plasmid can readily be separated from plasmid that has been cleaved in a single-stranded manner (nicked, form II) and in a double-stranded manner (linear, form III) by agarose gel electrophoresis. This study investigates the ability of ironbound ADR-925 and its desmethyl derivative EDTA-bisamide (5) to cleave supercoiled plasmid DNA in the presence of the reductant ascorbic acid under aerobic conditions. Additionally, thiourea, known to be a radical scavenger, is used to probe the mechanism of DNA cleavage.

\section{Materials and Methods}

Materials. EDTA-dianhydride, thiourea, $\mathrm{Na}_{2} \mathrm{Fe} e^{\prime \prime \prime} E D T A \Sigma 2 \mathrm{H}_{2} \mathrm{O}$, aqueous glycerol and boric acid (Aldrich); ascorbic acid and $\mathrm{FeCl}_{2}$ (Baker); Tris and bromphenol blue (BioRad); conc. $\mathrm{NH}_{4} \mathrm{OH}$, $\mathrm{NaCl}$ and $\mathrm{Na}_{2}$ EDTA (Fisher); agarose (EEO 0.9-0.13) and ethidium bromide (Sigma) were obtained in their highest available purity and used without further purification. ADR-925 (2) was generously provided by Pharmacia/Upjohn. Universal buffer was from Stratagene, and ECoR I and pBR322 plasmid solution $(0.25 \mu \mathrm{g} / \mu \mathrm{L}, 10 \mathrm{mM}$ Tris $\mathrm{HCl}, 5 \mathrm{mM} \mathrm{NaCl}, 0.1 \mathrm{mM}$ EDTA, pH 7.4) were from GibcoBRL. Barnsted Nanopure $(18 \mathrm{M} \Omega \mathrm{cm}$ ) water was used throughout, and all reaction equipment was acid-washed in $4.5 \mathrm{M} \mathrm{HCl}$ or concentrated sulfuric acid, or purchased metal-free.

Instrumentation. NMR spectra were obtained using a Varian Gemini $2000200 \mathrm{MHz}$ spectrometer equipped with a Sun Workstation. UV-VIS spectra were acquired on an Olis Cary-14 spectrophotometer interfaced to a Dell 310 microcomputer. IR spectra were obtained using a Perkin Elmer 1600 Series FTIR spectrophotometer. Solution sample and reaction $\mathrm{pH}$ were monitored with a Corning Model $340 \mathrm{pH}$ meter equipped with a Corning combination electrode. Electrophoresis was carried out in a Submarine Mini-gel Electrophoresis Unit (Sigma) with a BioRad PowerPac 300. Gels were visualized with an IS1000 Digital Imaging System (Alpha Innotech Corp.). 
Preparation of EDTA-bisamide (5). Ethylenediaminetetraacetic acid dianhydride $(6.60 \mathrm{~g}$, $25.8 \mathrm{mmol}$ ) was slowly stirred into an ice-cold $20 \mathrm{~mL}$ portion of concentrated $(28-30 \%)$ ammonium hydroxide. At room temperature, an additional $1 \mathrm{~mL}$ of conc. ammonium hydroxide was added, followed by $20 \mathrm{~mL}$ of water and 12-24 $\mathrm{h}$ of stirring. Solvent was then removed under reduced pressure, and the white solid was redissolved in $20 \mathrm{~mL}$ water and precipitated with concentrated $\mathrm{HCl}$. This was filtered under vacuum, washed twice with dry diethyl ether and vacuum desiccated overnight. Analysis: yields $>75 \%$; IR carbonyl bands (KBr): $1645.8 \mathrm{~cm}^{-1}\left(\mathrm{CONH}_{2}\right)$ and $1680.4 \mathrm{~cm}^{-1}(\mathrm{COOH}) ;{ }^{1} \mathrm{H}$ NMR $\left(\mathrm{D}_{2} \mathrm{O}\right.$; DSS internal standard) resonances: $2.9 \mathrm{ppm}\left(\mathrm{N}-\mathrm{CH}_{2}\right), 3.35 \mathrm{ppm}\left(\mathrm{CH}_{2} \mathrm{CO}_{2} \mathrm{H}\right), 3.5 \mathrm{ppm}\left(\mathrm{CH}_{2} \mathrm{CONH}_{2}\right)$.

Preparation and Characterization of Iron Complexes. Fe-EDTA was used as purchased. FeEDTA-bisamide and Fe-ADR-925 were freshly-prepared 10x in situ by mixture of appropriate amounts of EDTA-bisamide or ADR-925 (0.2 M stock) and ferrous chloride (0.04 M stock) and maintained at $\mathrm{pH} 5$. Resulting solutions were diluted into water for immediate use. EDTAbisamide and ADR-925 were used at $500 \mu \mathrm{M}$ regardless of iron concentration, which was at least in 4-fold excess over the iron complex. In aqueous solution, these complexes exist in both monomeric and dimeric forms. At $\mathrm{pH} \mathrm{5}$, the iron(III) EDTA-bisamide and ADR-925 monomers show one absorbance maximum at $258 \mathrm{~nm}$. The dimeric complexes (pH 7) exhibit shoulders at $247 \mathrm{~nm}, 271 \mathrm{~nm}, 308 \mathrm{~nm}$, and $341 \mathrm{~nm}$ and a maximum in the visible region at $475 \mathrm{~nm}$ and $540 \mathrm{~nm}(\mathrm{sh})$.

Base titrations were carried out at $23{ }^{\circ} \mathrm{C}$ and over $\mathrm{pH}$ ranges 4.0-6.9 and 4.2-8.2 for Fe-EDTA-bisamide and Fe-ADR-925, respectively. At higher $\mathrm{pH}$, the iron complexes become unstable towards precipitation. Iron(III) complexes $(100 \mu \mathrm{M})$ were generated in situ by the addition of $1: 1$ ferrous chloride to a stock solution of the ligand $(\mathrm{pH} \sim 5)$ and aerially oxidized to the iron(III) form over approximately $24 \mathrm{hrs}$. Throughout the titration, standardized, carbonate-free $\mathrm{NaOH}(\mathrm{aq})(0.1 \mathrm{M})$ was added with continuous stirring and under a blanket of $\mathrm{N}_{2(g)}$ to raise the $\mathrm{pH}$ approximately 0.2 units. Spectra and $\mathrm{pH}$ readings were obtained 10 minutes after each addition of base. During this $10 \mathrm{~min}$. interval, the $\mathrm{pH}$ drops and minimizes; kinetics of similar pH-jump experiments indicate dimer formation maximizes in 10 min., after which time a slower secondary process (most likely re-equilibration with the monomer species) takes place. Titrations at higher metal-complex concentrations, needed for monitoring dimer formation at $475 \mathrm{~nm}$, were unsuccessful due to precipitation.

Nicking Reactions. Each $20 \mu \mathrm{L}$ reaction was $10.2 \mathrm{mM}$ Tris $\mathrm{HCl}, 50.4 \mathrm{mM} \mathrm{NaCl}, 2.5 \mu \mathrm{M}$ EDTA, $0.1 \mathrm{mM}$ ascorbate, $10 \mu \mathrm{M}$ in base pairs of DNA, specified concentration of iron reagent and excess ligand, $\mathrm{pH} 7$. The DNA used was the pBR322 plasmid from $E$. coli, which is 4,361 base pairs and has a single, unique recognition site for the EcoR I endonuclease (which cleaves DNA in a double-stranded manner). Tris/ $\mathrm{NaCl}$ buffer $(\mathrm{pH} 7)$ with thiourea when appropriate $(17.5 \mu \mathrm{L})$ and DNA solution $(0.5 \mu \mathrm{L})$ were combined in a picofuge tube; 1.0 $\mu \mathrm{L}$ of freshly-prepared ascorbate $(2 \mathrm{mM}, \mathrm{pH} 7)$ and $1.0 \mu \mathrm{L}$ of freshly-prepared iron-reagent solution were placed on the side of the tube, and all reactions for each experiment were started nearly simultaneously by shaking the components of each tube together. Reactions proceeded at room temperature for $60 \mathrm{~min}$, and each was stopped by the addition of $5 \mu \mathrm{L}$ of a solution of $0.25 \%$ bromphenol blue in $30 \%$ aqueous glycerol and electrophoresed immediately.

(A) To confirm the relative electrophoretic mobilities of plasmid forms I, II and III, reactions with no iron reagent, with $100 \mu \mathrm{M}$ ferrous chloride and with a standard $20 \mu \mathrm{L}$ EcoR I digest were performed. (B) Fe-EDTA was studied at $1 \mu \mathrm{M}, 10 \mu \mathrm{M}$, and $100 \mu \mathrm{M}$ in the absence of thiourea. (C) Fe-EDTA-bisamide was studied at $1 \mu \mathrm{M}, 10 \mu \mathrm{M}, 50 \mu \mathrm{M}$ and $100 \mu \mathrm{M}$ in the absence of thiourea. (D) Fe-ADR-925 was studied at $10 \mu \mathrm{M}, 50 \mu \mathrm{M}$ and $100 \mu \mathrm{M}$ in the absence of thiourea. (E) In the presence of $5 \mathrm{mM}$ and $500 \mathrm{mM}$ thiourea, Fe-EDTA and FeEDTA-bisamide were studied at $10 \mu \mathrm{M}$.

For cleavage product analysis, gels were $1 \%$ agarose in $0.5 \times$ TBE $(45 \mathrm{mM}$ Trisborate, $1 \mathrm{mM}$ EDTA, $\mathrm{pH} 7.75$ ), and electrophoresis was conducted at room temperature in $0.5 \times$ TBE at $50 \mathrm{~V}$ for $3.5 \mathrm{~h}$. After electrophoresis, gels were stained in $0.5 \mu \mathrm{g} / \mathrm{mL}$ ethidium bromide for $1 \mathrm{~h}$ and then imaged and analyzed densitometrically under ultraviolet light. Note that small differences in staining make exact quantitative gel-to-gel comparisons difficult. Densitometry is uncorrected for differential uptake of ethidium bromide by supercoiled and non-supercoiled DNA. A previous study with pBR322 plasmid under similar conditions showed this factor was small. ${ }^{24}$ 


\section{Results of DNA Cleavage Experiments}

Controls indicated that plasmid not treated with iron reagent or endonuclease was at least $80 \%$ supercoiled. Treatment with $100 \mu \mathrm{M}$ ferrous chloride in the absence of ligand resulted in two bands of approximately equal densitometric intensity (the faster-migrating corresponding to the $80+\%$ band on the control), and endonuclease digestion resulted in a single intermediate band. This indicates that under the electrophoretic conditions chosen, supercoiled DNA migrates the fastest, linear DNA migrates intermediately, and nicked DNA migrates most slowly.

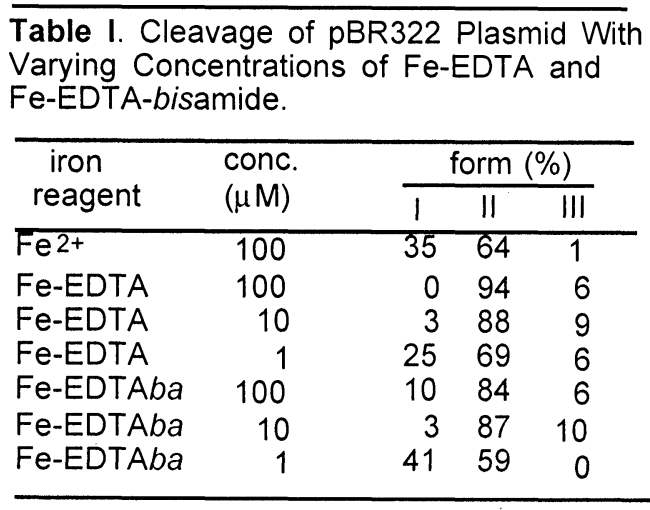

Relative densitometric intensities from UV imaging after ethidium bromide staining. DNA (10 $\mu \mathrm{M} \mathrm{bp}$ ), buffer (10 $\mathrm{mM}$ Tris $\mathrm{HCl}, 50 \mathrm{mM} \mathrm{NaCl}$, $2.5 \mu \mathrm{M}$ EDTA, pH 7), ascorbate (100 mM) and iron reagent reacted at room temperature for $60 \mathrm{~min}$.

\begin{tabular}{|c|c|c|c|c|}
\hline \multirow{2}{*}{$\begin{array}{l}\text { iron } \\
\text { reagent }\end{array}$} & \multirow{2}{*}{$\begin{array}{l}\text { conc. } \\
(\mu \mathrm{M})\end{array}$} & \multicolumn{3}{|c|}{ form $(\%)$} \\
\hline & & I & II & III \\
\hline $\mathrm{Fe}^{2+}$ & 100 & 30 & 70 & 0 \\
\hline Fe-EDTAba & 100 & 14 & 81 & 5 \\
\hline Fe-EDTAba & 50 & 7 & 88 & 5 \\
\hline Fe-EDTAba & 10 & 7 & 86 & \\
\hline Fe-ADR-925 & 100 & 4 & 91 & 5 \\
\hline Fe-ADR-925 & 50 & 6 & 89 & \\
\hline Fe-ADR-925 & 10 & 13 & 82 & \\
\hline
\end{tabular}

Relative densitometric intensities fri UV imaging after ethidium bromide staining. Same conditions as in Ta

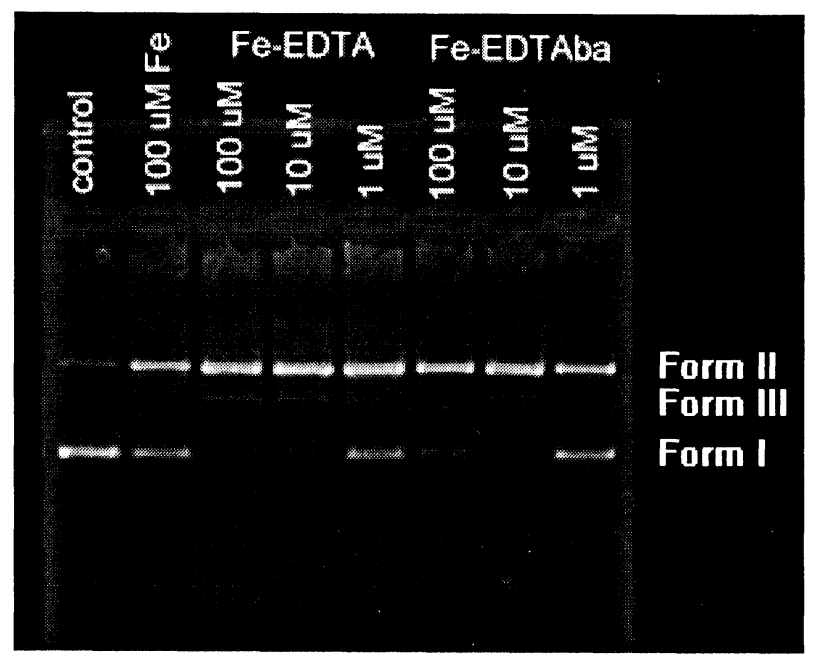

Figure 1. UV-visualized agarose gel of the pBR322 plasmid cleavage products after reaction with $\mathrm{Fe}$ EDTA and Fe-EDTA-bisamide $(1-100 \mu \mathrm{M})$. Supercoiled DNA is Form I, nicked is Form II, and linear is Form III.

DNA was cleaved by the Fe-EDTA-bisamide under Fenton conditions. At $100 \mu \mathrm{M}, \mathrm{Fe}-$ EDTA and Fe-EDTA-bisamide both cleaved the plasmid with greater efficiency than ferrous chloride (Table 1). At $10 \mu \mathrm{M}$, Fe-EDTA and Fe-EDTA-bisamide cleaved the DNA with approximately equal efficiency. However, Fe-EDTA cleaved the DNA more efficiently than Fe-EDTA-bisamide at both $1 \mu \mathrm{M}$ and $100 \mu \mathrm{M}$; this is especially unusual, since Fe-EDTAbisamide cleaved the DNA less efficiently at $100 \mu \mathrm{M}$ (the higher concentration) than at 10 $\mu \mathrm{M}$ (Figure 1). Fe-ADR-925 (the iron-bound hydrolysis product of dexrazoxane) was also able 
to cleave DNA (Table II), and did so with approximately equal efficiency to Fe-EDTAbisamide at $50 \mu \mathrm{M}$. However, like Fe-EDTA, Fe-ADR-925 cleaves DNA with increasing efficiency as concentration increases between $10 \mu \mathrm{M}$ and $100 \mu \mathrm{M}$ (as opposed to Fe-EDTAbisamide).

\begin{tabular}{|c|c|c|c|c|}
\hline \multirow{2}{*}{$\begin{array}{l}\text { iron } \\
\text { reagent }\end{array}$} & \multirow{2}{*}{$\begin{array}{l}\text { thiourea } \\
\text { conc. }(\mathrm{mM})\end{array}$} & \multicolumn{3}{|c|}{ form (\%) } \\
\hline & & 1 & II & III \\
\hline $\mathrm{Fe}^{2+}$ & 0 & 49 & 51 & 0 \\
\hline $\mathrm{Fe}^{2+}$ & 5 & 81 & 19 & 0 \\
\hline Fe-EDTA & 0 & 0 & 97 & 3 \\
\hline Fe-EDTA & 5 & 53 & 47 & 0 \\
\hline Fe-EDTA & 500 & 92 & 8 & 0 \\
\hline Fe-EDTAba & 0 & 0 & 95 & 5 \\
\hline Fe-EDTAba & 5 & 48 & 52 & 0 \\
\hline Fe-EDTAba & 500 & 88 & 12 & 0 \\
\hline
\end{tabular}

Relative densitometric intensities from UV imaging after ethidium bromide staining. Iron reagent is $10 \mu \mathrm{M}$. Other conditions same as Table 1.

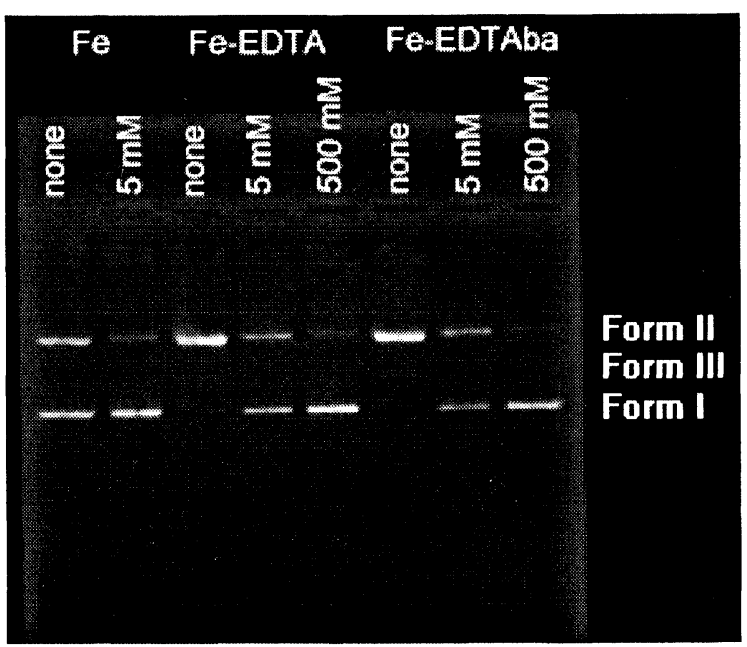

Figure 2 Thiourea inhibition of DNA cleavage by $\mathrm{Fe}^{2+}$, Fe-EDTA and Fe-EDTA-bisamide. Iron reagents were $10 \mu \mathrm{M}$, and thiourea was $0-500 \mathrm{mM}$ (thiourea concentration is indicated over each lane). Same visualization as in Figure 1.

The cleavage of DNA in the presence of ferrous chloride, Fe-EDTA and Fe-EDTA-bisamide (all at $10 \mu \mathrm{M}$ ) was inhibited by the radical scavenger thiourea (Table III). At $5 \mathrm{mM}$ thiourea, cleavage by ferrous chloride was almost entirely retarded, and cleavage by Fe-EDTA and $\mathrm{Fe}$ EDTA-bisamide was reduced by half. Thiourea at $500 \mathrm{mM}$ approximately completely prevented DNA cleavage (Figure 2).

Discussion

Razoxane, like other EDTA-diimide drugs (ICRF-154, dexrazoxane), is an antineoplastic, and this is probably due at least in part to inhibition of topoisomerase $11 ., 5$ At lower doses, dexrazoxane, which is simply enantiomerically-pure razoxane, ameliorates the cardiotoxicity of doxorubicin therapy. ${ }^{1}$ However, such diimides are also carcinogenic, and both razoxane and dexrazoxane hydrolyze in vivo to metal-ion chelators that can produce 
hydroxyl radicals when bound to iron under Fenton conditions. ${ }^{6,10,15}$ This study illustrates that this chemistry can cleave DNA, and further suggests that this DNA cleavage is by hydroxyl radical, since it is inhibited by the radical scavenger thiourea.

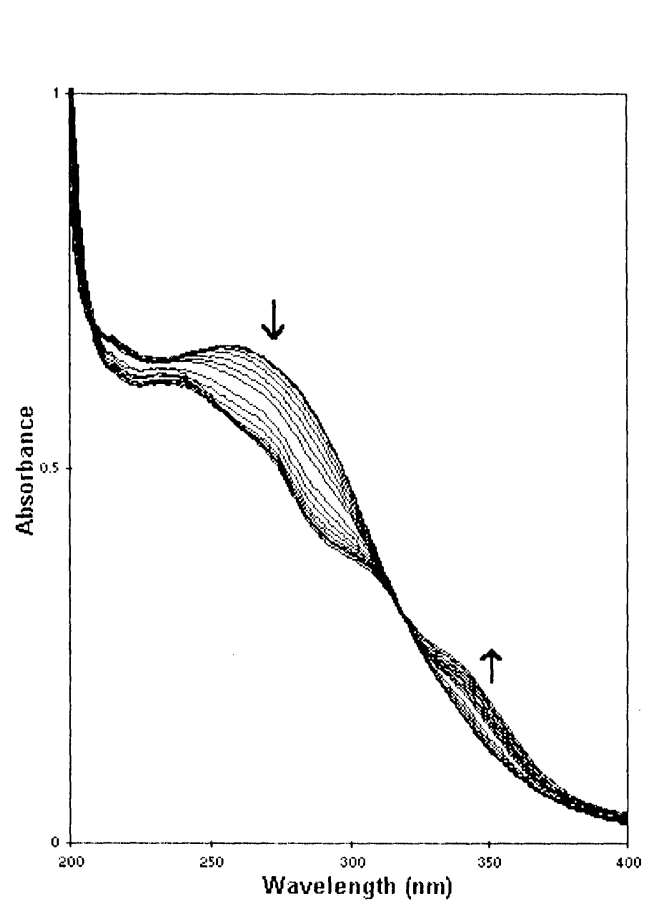

a)

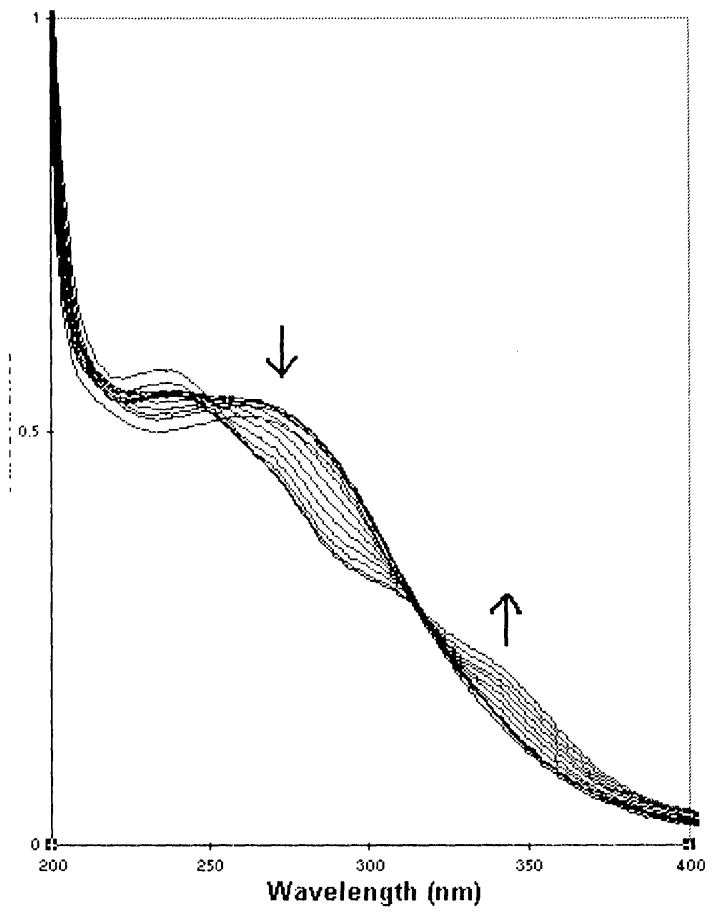

b)

Figure 3 Ultraviolet absorption spectral changes for a) Fe-EDTA-bisamide and b) Fe-ADR-925 upon base titration. Iron complexes were $100 \mu \mathrm{M}$. The $\mathrm{pH}$ ranges were 4.0-6.9 for Fe-EDTA-bisamide and 4.2-8.2 for Fe-ADR-925. At higher $\mathrm{pHs}$, the iron complexes become unstable toward iron hydroxide and oxide formation and precipitation.

Our lab has observed that high (preparative) concentrations of ferrous chloride and EDTA-bisamide result in an initially yellow solution that turns brown over time at relatively low $\mathrm{pH}$. UV studies have indicated that this is a secondary base-catalyzed reaction after complex formation, and spectrophotometric similarities between this reaction and formation of the Fe-EDTA $\mu$-oxo dimer suggest that such $\mu$-oxo dimerization may be occurring with $\mathrm{Fe}$ EDTA bisamide and Fe-ADR-925, as well (Figure 3). Dimer formation for Fe-ADR-925 begins at higher basicity (pH 6) than for Fe-EDTA-bisamide ( $\mathrm{pH}$ 5), perhaps because the methyl substituent on ADR-925 decreases the Lewis acidity of the iron in that complex. ${ }^{25}$ Attermpts to determine dimerization constants by spectrophotometric titrations have been hindered by precipitation problems under the conditions needed for this analysis. ${ }^{26}$ Further attempts to obtain these constants kinetically have likewise proven difficult due to mechanistic complexities. More work is needed, and a full analysis of this system is ongoing in our lab. The higher pHs at which Fe-EDTA and Fe-ADR-925 undergo monomer-dimer equilibrium, however, correspond well with the differential concentration/cleavage profiles of Fe- EDTAbisamide, Fe-ADR-925 and Fe-EDTA. The inhibition of these DNA scission reactions by thiourea probably does not rule out either additional oxidizing species or modes of inhibition in addition to radical scavenging. In particular, thiourea might react with other electrondeficient species that could cleave DNA, and might also be binding to the metal center. The former is particularly worth further investigation since the ferryl species [Fe ${ }^{\mathrm{IV}}=\mathrm{O}$ (EDTAbisamide)] would be neutral as opposed to $\left[\mathrm{Fe}^{1 \mathrm{~V}}=\mathrm{O}(\mathrm{EDTA})\right]^{2-}$, which would be negative (same as the DNA backbone).

We would like to suggest that the ability of the iron-bound hydrolysis products of dexrazoxane and ICRF-154 to cleave DNA might account for the carcinogenic nature of the diimide drugs, and this implies a therapeutic limit to dexrazoxane. Furthermore, it does not seem clear at this time that such a route might not also be a substantial contributor to the in 
vivo mechanism of the antitumor activity by razoxane. Most importantly, the production of the very same oxidizing species, HOE, that is taken to be responsible for doxorubicin toxicity at least suggests that there may be a maximum dose for doxorubicin/dexrazoxane combination. Moreover, the relative ease with which Fe-EDTA-bisamide and Fe-ADR-925 form dimers at near physiological $\mathrm{pH}$ suggests that the local concentration in vivo may be important to the iron-bound drug's overall reactivity. This calls for further chemical and, especially, clinical study.

\section{Acknowledgments}

The authors extend their gratitude to Dr. Anthony Imondi of Pharmacia/Upjohn for advice and samples of ADR-925, and to Professor David Marcey of Kenyon College. Additional thanks to Professors Thomas Tullius of Johns Hopkins University and A. Graham Lappin of the University of Notre Dame for helpful conversation relating to technical issues of this study and to Douglas Scheftner for preliminary work. Funding for this project was generously provided by a Robert J. Tomsich Award (Kenyon College, TJM and RAM) and a Research Corporation Award CC3833 (RAM).

\section{References}

1. Hellmann, K.; Franks, C.R. Contrib. Oncol. 1995, 48, 40-47.

2. Doroshow, J.H. ACS Symp. Ser. 574, 1995, 259-267

3. Marusak, R.A.; Meares, C.F. Active Oxygen in Biochemistry (Valentine, J.S.; Foote, C.S.; Greenberg, A.; Liebman, J.F. Eds.) New York: Blackie Academic and Professional, 1995 pp 336-400.

4. Creighton, A.M.; Hellmann, K; Whitecross, S. Nature 1969, 222, 384-385.

5. Herman, E.H.; Witiak, D.T.; Hellmann, K; Waravdekar, V.S. Adv. Pharm. Chemo. 1982, 19, 249-290.

6. Xue, Y.; Lu, D.; Guo, Y.; Lin, B. Leukemia Research 1992, 16, 1113-1123.

7. Tanabe, K.; Ikegami, Y.; Ishida, R.; Andoh, T. Cancer Res. 1991, 51, 4903-4908.

8. Roca, J.; Ishida, R.; Berger, J.M.; Andoh, T.; Wang, J.C. Proc. Natl. Acad. Sci. USA 1994, 91, 1781-1785.

9. Ishida, R.; Hamatake, M.; Wasserman, R.A.; Nitiss, J.L.; Wang, J.C.; Andoh, T. Cancer Res. 1995, 55, 2299-2303.

10. Dawson, K.M. Biochem. Pharm. 1975, 24, 2249-2253.

11. Albanese R.; Watkins, P.A. Br. J. Cancer 1985, 52, 725-731.

12. Wadler, S.; Green, M.D.; Basch, R.; Muggia, R.M. Biochem. Pharm. 1987, 36, 1495-1501.

13. Imondi, A.R.; Dellatorre, P.; Mazue, G.; Sullivan, T.M.; Robbins, T.L.; Hagerman, L.M.; Podesta, A.; Pinciroli, G. Cancer Res. 1996, 56, 4200-4204.

14. Hasinoff, B.B. Agents and Actions 1989, 26, 378-385.

15. Thomas, C.; Vile, G.F.; Winterbourn, C.C. Biochem. Pharm. 1993, 45, 1967-1972.

16. Malisza, K.L.; Hasinoff, B.B. Arch. Biochem. Biophys. 1995, 316, 680-688.

17. Hasinoff, B.B. Free Rad. Res. 1995, 22, 319-325.

18. Pogozelski, W.K.; McNeese, T.J.; Tullius, T.D. J. Am. Chem. Soc. 1995, 117, 6428-6433.

19. Hertzberg, R.P.; Dervan, P.B. J. Am. Chem. Soc. 1982, 104, 313-315.

20. Iverson, B.L.; Shreder, K.; Morishima, T.; Rosingana, M.; Sessler, J.L. J. Org. Chem. 1995, 60, 6616-6620.

21. Chang, C.-H.; Meares, C.F. Biochemistry 1982, 24, 6332-6334.

22. Shepherd, R.E.; Lomis, T.J.; Koepsel, R.R.; Hegde, R.; Mistry, J.S. Inorg. Chim. Acta 1990, 171, 139-149.

23. Morrow, J.R.; Kolasa, K.A. Inorg. Chim. Acta 1992, 195, 245-248.

24. Hertzberg, R.P.; Dervan, P.B. Biochemistry 1984, 23, 3934-3945.

25. Schugar, H.J.; Hubbard, A.T.; Andson, F.C.; Gray, H.B. J. Am. Chem. Soc. 1969, 90, 7177.

26. As defined by Sillén, L. G. Quart. Rev. (London), 1959, 13, 146-168.

Received: February 12, 1997 - Accepted: February 20, 1997 Received in revised camera-ready format: May 26, 1997 